\title{
VYUŽITIE NÁSTROJA DAQ V DOPRAVNO-PSYCHOLOGICKOM VÝSKUME
}

\section{USING DAQ TOOL FOR RESEARCH IN TRAFFIC-PSYCHOLOGY}

\author{
Kristián Čulík ${ }^{1, *}$, Alica Kalašová ${ }^{1}$, Ambróz Hájnik ${ }^{1}$
}

\begin{abstract}
Abstrakt
Bezpečnost' cestnej premávky a s tým spojená ochrana l'udského života je cielom v každej vyspelej krajine. Viac ako 90\% dopravných nehôd po celom svete je spôsobených l'udskou chybou. Z toho vyplýva jednoznačná povinnost' zaoberat' sa l'udskou psychikou a predovšetkým páchaním priestupkov vodičmi na cestách. Dopravno-psychologický výskum obsiahnutý v tomto článku bol realizovaný na vzorke takmer štyristo respondentov, pričom išlo o mladých vodičov vo veku 18 až 26 rokov. Na výskum bol použitý dotazník postojov vodiča, ktorého výsledky boli následne porovnávané so všeobecnými údajmi tiež zist'ovanými v prieskume. Výsledky bolo v globále možné porovnávat' aj so zahraničnými štúdiami, pretože dopravno-psychologický nástroj, ktorý bol využitý má presne stanovenú štruktúru a je možné ho použit'v akejkol'vek krajine. Ciel'om výskumu bolo predovšetkým hl'adanie štatistických podobností medzi výsledkami nástroja DAQ a uvedeným počtom a druhom dopravných priestupkov respondentov. Taktiež je cielom porovnanie dosiahnutých výsledkov s inými štúdiami, ktoré získali dáta rovnakým nástrojom.
\end{abstract}

Klíčová slova dopravná bezpečnost', psychológia, $D A Q$, vodič

Summary Road safety and protection of human life on the road infrastructure is a goal in every developed country. More than 90\% of road accidents worldwide are caused by human error. This implies a clear obligation to deal with the human psyche and, above all, committing offences on the road. The traffic-psychological research contained in this article was performed on a sample of almost four hundred respondents; young drivers aged 18 to 26 years. A questionnaire of the driver's attitudes was used for the research, the results of which were subsequently compared with the general data also found in the survey. Globally, it was also possible to compare the results with foreign studies, because the trafficpsychological tool that was used has a precisely defined structure and can be used in any country. The aim of the research was primarily to find statistical similarities between the results of the DAQ tool and the stated number and type of traffic offences of the respondents. The aim is also to compare the own results with other studies that obtained data with the same tool.

Keywords $\quad$ traffic safety, psychology, DAQ, driver

\section{1 ÚVOD}

Tento príspevok sa zameriava na otázku dopravnej psychológie a dopravnej bezpečnosti. Bezpečnost' na pozemných komunikáciách podl'a Kalašovej (2017) ovplyvňujú tri klúčové faktory: človek, vozidlo a prostredie. Vodič predstavuje najvyššie riziko bezpečnosti cestnej premávky. Literatúra, napr. Isaac et al. (2002), spravidla uvádza, že viac ako 90\% dopravných nehôd je spôsobených l'udskou chybou. Z toho

\footnotetext{
1 Žilinská univerzita v Žiline, Fakulta prevádzky a ekonomiky dopravy a spojov, Katedra cestnej a mestskej dopravy, Univerzitná 1, 01026 Žilina, Slovenská republika

* korešpondenčný autor, tel.: +421 914116 313, e-mail: kristian.culik@fpedas.uniza.sk
} 
dôvodu je výskum interakcie medzi vodičom, vozidlom a prostredím efektívnym procesom a motivuje výskumníkov po celom svete k práci v oblasti bezpečnosti cestnej premávky a dopravnej psychológie. Na dôvažok možno spomenút', že s postupným zavádzaním autonómnych vozidiel s rôzne vysokým stupňom automatizácie, sa téma bezpečnosti človeka v dopravnom systéme stáva ešte aktuálnejšou.

Na otázku prečo sa zaoberat' práve psychológiou vodičov odpovedajú predovšetkým exaktné čísla o počte dopravných nehôd. Vzhl'adom na to, že nástroj DAQ sa používa na odhal'ovanie tendencie vodičov páchat' štyri druhy dopravných priestupkov, príslušná štatistika je nasledujúca podla štatistík PZ SR:

- počet dopravných nehôd v Slovenskej republike za rok 2019 bol 13 741:

o z toho 1669 dopravných nehôd, ktorých príčinou vzniku bola nedovolená rýchlost' jazdy (ide o $12 \%$ z celkového počtu dopravných nehôd, pokles oproti roku 2018 o 207),

o z toho 582 dopravných nehôd, ktorých príčinou vzniku bolo nedodržanie vzdialenosti medzi vozidlami (ide o 4\% z celkového počtu dopravných nehôd, pokles oproti roku 2018 o 48),

o z toho 258 dopravných nehôd, ktorých príčinou vzniku bolo nesprávne predchádzanie (ide o 2\% z celkového počtu dopravných nehôd, pokles oproti roku 2018 o 54),

o z toho 1577 dopravných nehôd, ktoré boli zavinené pod vplyvom alkoholu (ide o 12\% z celkového počtu dopravných nehôd),

- 86\% z nich, teda 1356 dopravných nehôd, spôsobili vodiči motorových vozidiel,

- $7 \%$ z nich, teda 112 dopravných nehôd, spôsobili chodci,

- $6 \%$ z nich, teda 93 dopravných nehôd, spôsobili cyklisti.

Výskum popisovaný v tomto článku nie je zameraný na celú škálu vodičov. Zameranie bolo predovšetkým na vekovú skupinu 18 až 26 rokov, resp. vodiči s celkovou dížkou praxe do cca 8 rokov. Dopravnopsychologický prieskum s využitím špecializovaného dotazníka mal za ciel' jednak zozbierat' niektoré základné údaje ako aj odpovede na konkrétne otázky a následne tieto využit' pri štatistickej analýze dát. Skratky použité v texte sú nasledovné: A - vážený priemer, Mo - modus, Me - medián, SD - smerodajná odchýlka.

\section{DOPRAVNO-PSYCHOLOGICKÝ PRIESKUM}

Najjednoduchší spôsob výskumu l'udského správania je možnost' opýtat' sa ako sa obyčajne správajú prostredníctvom dotazníka. Takýmto spôsobom je pomerne jednoduché kedykol'vek získat' tieto informácie pomerne l'ahko a za akékol'vek časové obdobie. Iné metódy predikcie dopravných nehôd, ako napr. lekárske vyšetrenia, vychádzajú len z aktuálneho somatického stavu. Objektívne - technické merania jazdného správania sú často obmedzené zvyčajne na vel'mi krátky čas zberu údajov. Je dôležité poznamenat', že iba niektoré dotazníky z dopravnej psychológie sa dočkali širšieho využitia a neboli využité iba lokálnych štúdiách.

\subsection{Definícia nástroja DAQ}

Unifikovaným dotazníkom, ktorý bol využitý v našom výskume nesie skratku DAQ alebo v niektorej literatúre - podl'a Rolisona a Moutariho (2020) alebo Gheorghiua a Havârneanua (2012) aj MDAQ (The Manchester Driver Attitude Questionnaire). Tento dotazník bol vytvorený vo Vel'kej Británii v roku 1990.

Je vhodné spomenút', že tento nástroj výskumu z oblasti dopravnej psychológie má ešte d'alšie dva príbuzné dotazníky na výskum aberantného správania DBQ alebo MDBQ (Manchester Driver Behaviour Questionnaire) a dotazník SCQ (Safety Climate Questionnaire), ktorý sa týka bezpečnostnej klímy v podnikoch dopravy, tzn. je zameraný na to, ako vnímajú vodiči svojich zamestnávatel'ov z hladiska bezpečnosti cestnej dopravy. Viac informácií je v štúdiách Martinussena et al. (2014) a Wintera a Dodoua (2010). Porovnanie zloženia týchto troch súvisiacich dotazníkov je v tab. 1. 
Tab. 1 Porovnanie položiek súvisiacich nástrojov; zdroj: autori

\begin{tabular}{clc}
\hline Nástroj & Zameranie položiek & Počet položiek \\
\hline \multirow{3}{*}{ DBQ } & Chyby vodiča & 8 \\
& Porušenia pravidiel cestnej premávky & 8 \\
& Agresívne prejavy & 4 \\
\hline \multirow{5}{*}{ DAQ } & Alkohol za volantom (A) & 5 \\
& Nedodržiavanie bezpečnej vzdialenosti (V) & 5 \\
& Riskantné predchádzanie (P) & 5 \\
& Prekračovanie rýchlosti (R) & 5 \\
\hline \multirow{5}{*}{ SCQ-MD } & Pravidlá bezpečnosti flotily & 3 \\
& Komunikácia a podpora & 8 \\
& Pracovný tlak & 8 \\
& Primeranost' procesov & 3 \\
& Záväzok manažmentu & 7 \\
\hline
\end{tabular}

\subsection{Faktorová analýza nástroja DAQ}

Nástroj DAQ je dotazník so 40 položkami a slúži na kvantifikáciu správania vodiča pri jazde takým spôsobom, aby boli identifikované 4 faktory:

- jazda pod vplyvom alkoholu,

- zámerné nedodržovanie bezpečnej vzdialenosti,

- nebezpečné predchádzanie,

- prekračovanie rýchlosti.

Respondenti majú v tomto dotazníku vyjadrit' súhlas alebo nesúhlas s výrokmi o ich vodičskom správaní. V tomto prípade je použitá 5-bodová stupnica, kde 1 znamená „úplne súhlasím“ a hodnota 5 znamená „absolútne nesúhlasím“.

Znenie otázok bolo podl'a možnosti čo možno najzrozumitel'nejšie preložené do slovenčiny. Znenie otázok môže byt' v jednotlivých štúdiách líšit', ale znenie použité v tejto práci pochádza zo štúdie Jongena et al. (2011). V tejto štúdii bolo použitých až 40 otázok. Niektoré otázky sú však v našich podmienkach nepoužitel'né (napr. tolerancia vplyvu alkoholu) alebo sa opakujú. Preto boli vybraté otázky podl'a faktorov tak, aby bol zachovaný počet 5 otázok na 1 faktor (tab. 2).

Tab. 2 Faktorová analýza nástroja DAQ; zdroj: autori

\begin{tabular}{clcl}
\hline Faktor & Názov faktora & $\begin{array}{c}\text { Príslušné otázky } \\
\text { (pôvodné) }\end{array}$ & $\begin{array}{c}\text { Príslušné otázky } \\
\text { (nový dotazník) }\end{array}$ \\
\hline $1(\mathrm{~A})$ & Alkohol za volantom & $3,5,12,22,24$ & $2^{*}, 4,6,10^{*}, 12$ \\
$2(\mathrm{~V})$ & Nedodržiavanie bezpečnej vzdialenosti & $1,15,23,28,31$ & $1,7,11^{*}, 15,17^{*}$ \\
$3(\mathrm{P})$ & Riskantné predchádzanie & $7,21,27,29,33$ & $5^{*}, 9^{*}, 14^{*}, 16,19^{*}$ \\
$4(\mathrm{~S})$ & Prekračovanie rýchlosti & $4,20,26,32,36$ & $3,8^{*}, 13^{*}, 18^{*}, 20^{*}$ \\
\hline
\end{tabular}

Opät' je tu možnost' porovnávat' výsledky so zahraničnými štúdiami, napr. Wishart et al. (2006), na ktorej bolo oslovených 1440 l'udí mailom, pričom sa podarilo získat' 443 odpovedí. Táto štúdia uvádza, že respondenti považujú v priemere za najneprijatel'nejšie správanie jazdu pod vplyvom alkoholu $(M=3,71)$ a riskantné predchádzanie. Naopak najviac tolerantní boli voči prekročeniu rýchlosti $(\mathrm{M}=2,76)$. Podrobnejšie sú výsledky porovnané s vlastným výskumom v kapitole 3.2. 
V nasledujúcich riadkoch je uvedené presné znenie prvých piatich otázok dotazníka ako príklad prekladu. Ostatné otázky sú v podobnom znení:

1. Vo všeobecnosti si l'udia neuvedomujú nebezpečenstvo vyplývajúce z nedodržiavania bezpečnej vzdialenosti medzi vozidlami.

2. Je pre mňa t’ažké sa zabavit', ked' všetci popíjajú a ja nesmiem, pretože robím ostatným vodiča.

3. Bol by som rád, keby sa viac dodržiavajú maximálne povolené rýchlosti.

4. Ciel'om polície by malo byt' eliminovanie čo najväčšieho počtu vodičov, ktorí si sadajú za volant pod vplyvom alkoholu.

5. Myslím si, že prechádzanie v rizikových situáciách je $v$ poriadku v prípade, že je v rámci mojich schopností.

\subsection{Spôsob vykonania prieskumu}

Dopravno-psychologický prieskum bol vykonaný čisto fyzickou - papierovou formou. Respondentmi boli študenti Žilinskej univerzity vo veku 18 až 26 rokov. Minimálna vzorka respondentov bola stanovená pomocou internetového nástroja Sample Size Calculator. Ako základná vzorka bol použitý údaj o počte vydaných vodičských preukazov podl'a veku, teda celkom $89433+164426=253859$ vodičov. Sample Size Calculator vyžaduje ešte nasledujúce parametre:

- Hladina spol'ahlivosti (Confidence Level), najčastejšie sa využíva 95\%, z toho dôvodu bola využitá táto štandardná hodnota.

- Interval spol'ahlivosti alebo konfidečný interval (Confidence Interval) je v štatistike typ intervalového odhadu neznámeho parametra, v našom prípade volíme 5.

- Celkový počet štatistických jednotiek základného súboru (Population) je v tomto prípade 3634503, teda ešte predimenzovaný počet vodičov v zvolenej vekovej kategórii.

Výsledkom je kalkulácia minimálnej vzorky, ktorá je v tomto prípade 384, teda je nutnost’ získat’ minimálne takýto počet dotazníkov.

\section{VÝSLEDKY VÝSKUMU}

Celkovo sa výskumu zúčastnilo 384 respondentov, z ktorých bolo 223 mužov (58\%) a 161 žien (42\%). Z hl'adiska vodičskej praxe uvádzali respondenti minimálnu hodnotu ubehnutých kilometrov $50 \mathrm{~km}$ a maximálnu hodnotu $500000 \mathrm{~km}(\mathrm{~A}=62629 \mathrm{~km}, \mathrm{Me}=30000 \mathrm{~km}, \mathrm{Mo}=10000 \mathrm{~km}, \mathrm{SD}= \pm 84688 \mathrm{~km})$. Na obr. 1 je graf počtu respondentov podl'a ich dížky vodičskej praxe v rokoch, z ktorého vidiet', akú vzorku vodičov sa podarilo zachytit'.

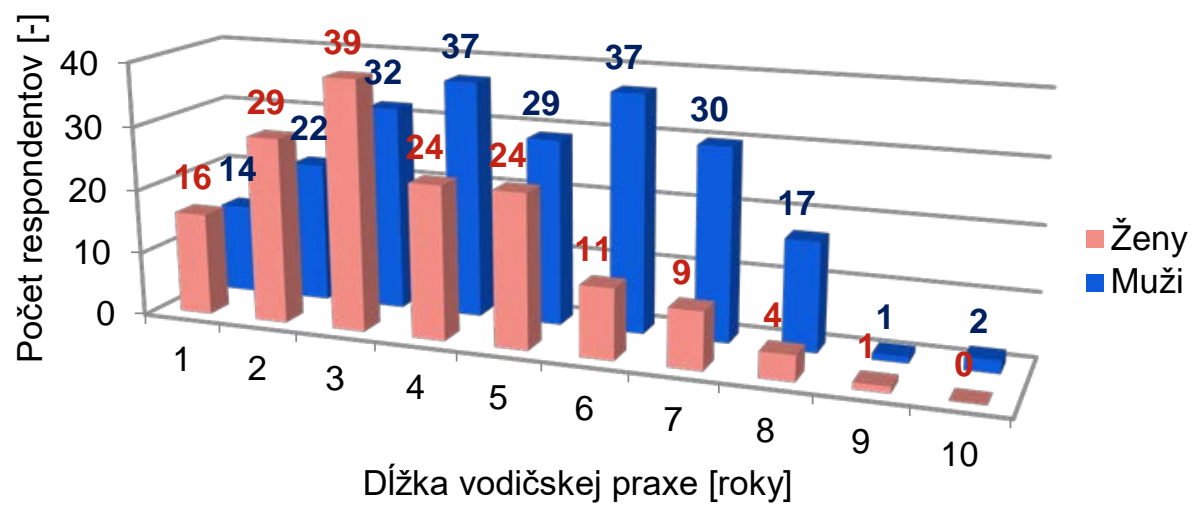

Obr. 1 Počet respondentov podl'a dížky vodičskej praxe a pohlavia; zdroj: autori 


\subsection{Výsledky nástroja DAQ}

Zaujímavé výsledky poskytujú priemery tolerancie vodičov voči jednotlivým priestupkom. Na nasledujúcom obrázku (obr. 2) je graf tolerancie vodičov k jednotlivým typom priestupkov. Vodiči 1 sú vyfiltrovaní respondenti, ktorí neoznačili uloženie pokuty za rýchlost'. Vodiči 2 sú respondenti, ktorí už vo svojej vodičskej praxi dostali minimálnej jednu sankciu za prekročenie maximálnej povolenej rýchlosti. Z grafu možno pozorovat', že tolerancia oboch skupín vodičov je takmer rovnakej úrovni aj pri alkohole aj pri nedodržiavaní bezpečnej vzdialenosti. Vodiči, ktorí v minulosti dostali pokutu za rýchlost’ majú väčšiu psychickú toleranciu voči takémuto priestupku vpriemere o $8 \%$ a zhodne o $8 \%$ aj toleranciu voči nebezpečnému predchádzaniu.

Tolerancia vodičov $\mathrm{k}$ priestupkom

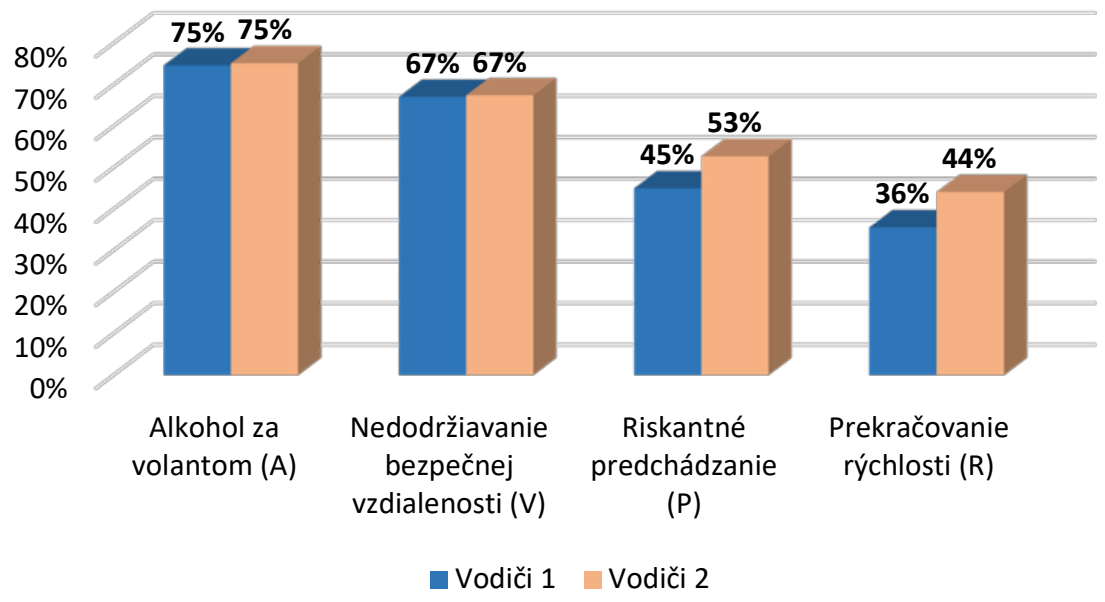

Obr. 2 Porovnanie tolerancie k priestupkom vodičov bez pokuty za rýchlost' (1) a s pokutou (2)

Podobne možno jednoduchým spôsobom z dopravno-psychologického prieskumu vyfiltrovat' respondentov, ktorí v minulosti dostali akúkol'vek pokutu. Ak voči sebe postavíme takéto dve skupiny, výsledky možno porovnat' grafom na obr. 3.

\section{Tolerancia vodičov k priestupkom}

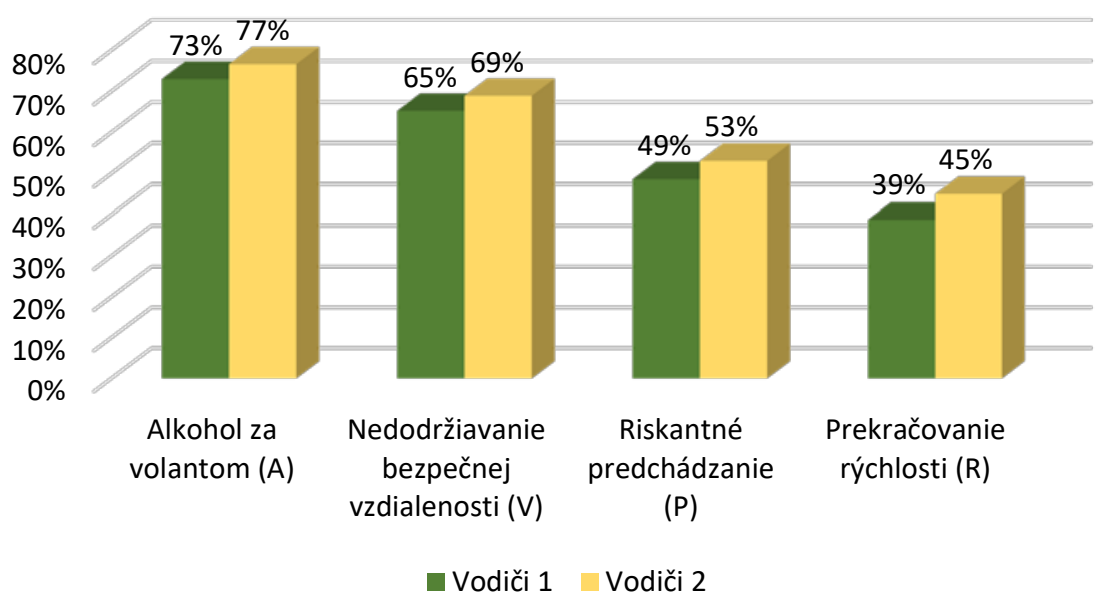

Obr. 3 Porovnanie tolerancie k priestupkom vodičov bez pokút (1) a s aspoň jednou pokutou (2) 
Z obr. 3 je zrejmé, že vodiči, ktorí ešte nedostali pokutu vo svojej vodičskej praxi majú k páchaniu priestupkov nižšiu toleranciu - nižší sklon a to:

- o 3,66\% pri faktore „Alkohol za volantom“,

- o 3,68\% pri faktore „Nedodržiavanie bezpečnej vzdialenosti“,

- o $4,48 \%$ pri faktore „Riskantné predchádzanie“,

- o 6,23\% pri faktore „Prekračovanie rýchlosti“.

Pri dopravno-psychologických nástrojoch, akým je aj DAQ sa často skúmajú aj vzájomné vnútorné vzt’ahy medzi faktormi. Tieto je možné odhalit’ napr. pomocou koeficientu korelácie v programoch SPSS alebo MS Excel. Koeficient korelácie meria obojstrannú lineárnu závislost’ dvoch premenných a nadobúda hodnoty z intervalu $\langle-1 ; 1\rangle$. Z vlastností kovariancie pre koeficient korelácie platia tieto implikácie:

- $\rho=0 \Leftrightarrow$ premenné $X$ a $Y$ nie sú lineárne závislé,

- $\rho>0 \Leftrightarrow$ medzi premennými $X$ a $Y$ je priamy lineárny vzt'ah,

- $\rho<0 \Leftrightarrow$ medzi premennými $X$ a $Y$ je nepriamy lineárny vzt'ah.

Koeficient korelácie $r_{x y}$ je určený vzt’ahom (1):

$$
r_{x y}=\frac{\operatorname{cov} x y}{s_{x} s_{y}}=\frac{n \sum x y-\sum x \sum y}{\sqrt{\left[n \sum x^{2}-\left(\sum x\right)^{2}\right] \cdot\left[n \sum y^{2}-\left(\sum y\right)^{2}\right]}}
$$

Tab. 3 Vnútorné vzt’ahy medzi faktormi nástroja DAQ; zdroj: autori

\begin{tabular}{llcccc}
\hline & \multicolumn{1}{c}{ FAKTOR } & A & V & P & R \\
\hline $\mathbf{1}$ (A) & Alkohol za volantom & 1 & & & \\
$\mathbf{2}$ (V) & $\begin{array}{l}\text { Nedodržiavanie } \\
\text { bezpečnej vzdialenosti }\end{array}$ & 0,440973 & 1 & & \\
$\mathbf{3}$ (P) & Riskantné predchádzanie & 0,183799 & 0,325551 & 1 & \\
$\mathbf{4}(\mathbf{R})$ & Prekračovanie rýchlosti & 0,023973 & 0,195693 & 0,459406 & 1 \\
\hline
\end{tabular}

Tab. 3 zobrazuje koeficienty korelácie medzi jednotlivými faktormi nástroja DAQ. Matica je logicky symetrická po diagonále, preto jej horná polovica nie je uvedená. Medzi všetkými dvojicami sa prejavila priama závislost’ rôznych hodnôt. Najvyššiu závislost' medzi faktormi možno pozorovat' medzi faktorom prekračovanie rýchlosti a riskantným predchádzaním na úrovni $\mathrm{r}=0,4594$ na hladine významnosti $\mathrm{p}=$ 0,01 . Podobne vel'ký vzájomný súvis sa objavil aj medzi druhou dvojicou faktorov - nedodržiavaním bezpečnej vzdialenosti a toleranciou voči požitiu alkoholu pred jazdou a to $r=0,4410$ na hladine významnosti $p=0,01$. Takéto hodnoty korelácie sa môžu javit’ nízke. Podl’a Stankovianskej (1997) však závisí interpretácia koeficientu korelácie od kontextu. Ak by sme sa bavili o nejakom fyzikálnom zákone, potom hodnota koeficientu korelácie 0,8 je vel'mi nízka, naopak v sociálnych vedách je vel'mi vysoká. Vel'mi exaktnú pomôcku stanovil Cohen (1988), podl'a ktorého je možné koeficienty korelácie interpretovat’ v psychologickom výskume nasledovne:

- $\quad$ korelácia v absolútnej hodnote pod 0,1 je triviálna,

- $\quad$ korelácia v intervale 0,1 a 0,3 je malá,

- $\quad$ v intervale 0,3 a 0,5 je stredná,

- $\quad$ pri hodnotách nad 0,5 je vel'ká,

- $\quad$ korelácia 0,7 a 0,9 sa uvádza dokonca ako vel'mi vel'ká,

- $\quad$ a korelácia v intervale 0,9 a 1,0 ako takmer dokonalá. 


\subsection{Porovnanie výsledkov aplikácie nástroja DAQ}

V prípade použitia nástroja DAQ je možné porovnávat' dosiahnuté výsledky so zahraničnými štúdiami. Možno ho totižto považovat' za akýsi unifikovaný súbor otázok, ktorého prekladom sa však v žiadnom prípade nesmie stratit' význam. $V$ tomto článku sú vlastné výsledky výskumu porovnané so zahraničnou štúdiou, ktorú zostavil Wishart et al. (2006). Aby bolo možné urobit’ komplexné porovnanie, je potrebné zbierat' aj d'alšie údaje a to:

- vek respondenta,

- počet rokov vodičskej praxe,

- počet hodín strávených vedením vozidla za týždeň,

- počet ubehnutých kilometrov s vozidlom za týždeň,

- počet dopravných nehôd,

- počet pokút.

Je potrebné spomenút', že v spomínanej štúdii boli brané do úvahy len dopravné nehody a pokuty za posledných 12 mesiacov. Vo vlastnom výskume bolo uvažované s celou históriou priestupkov a dopravných nehôd, pretože širší interval umožňuje lepšie zistit’ závislosti.

Tab. 4 Koeficienty korelácie a ich porovnanie; zdroj: autori

\begin{tabular}{lccccccccccc}
\hline Faktor & Č. & 1 & 2 & 3 & 4 & 5 & 6 & 7 & 8 & 9 & 10 \\
\hline Riskantné \\
predchádzanie
\end{tabular}

*Korelácia je významná na hladine významnosti 0,05

**Korelácia je významná na hladine významnosti 0,01

Tab. 4 zobrazuje komplexnú maticu koeficientov korelácie medzi jednotlivými faktormi nástroja DAQ a tiež d'alšími údajmi o jednotlivých respondentoch. Vlastné výsledky sú zobrazené tučne (bold), ostatné koeficienty sú z porovnatel'nej štúdie Wisharta et al. (2006). Vlastný výskum sa realizoval prostredníctvom 384 respondentov, z ktorých 161 (42\%) bolo žien a 223 (58\%) mužov. Variačné rozpätie veku bolo od 18 do 26 rokov, priemerný vek 21,99 rokov. Porovnávacia štúdia bola vykonaná na 443 austrálskych vodičoch.

V tab. 4 možno vidiet', že štúdie sú v niektorých vnútorných vzt'ahoch podobné. Vel'mi vel'ká korelácia $(\mathrm{r}=$ 0,$77 ; p<0,01$ ) je logicky medzi praxou vyjadrenou v kilometroch a rokoch držania vodičského oprávnenia. 
Posledný - desiaty stĺpec tabul'ky zobrazuje koreláciu medzi počtom dopravných nehôd respondenta a ostatnými faktormi. Za zmienku v tomto prípade stojí korelácia $(r=0,18 ; p<0,01)$ medzi toleranciou knedodržiavaniu bezpečnej vzdialenosti a počtom pokút, resp. počtom dopravných nehôd. Počet dopravných nehôd do určitej miery súvisí aj s vekom vodiča $(r=0,26 ; \mathrm{p}<0,01)$, s počtom rokov vodičskej praxe $(r=0,31 ; p<0,01)$, počtom hodín vedenia vozidla za týždeň $(r=0,18 ; p<0,01)$, počtom ubehnutých kilometrov za týždeň $(r=0,20 ; \mathrm{p}<0,01)$. Dopravná nehoda je ale vel'mi náhodný a ojedinelý jav, ktorý je vel'mi t’ažké vysvetlit' napr. regresnou analýzou, pretože dokážeme vysvetlit' len do $20 \%$ príčin dopravných nehôd.

\section{ZÁVER}

Nástroj DAQ je nápomocný pri odhal'ovaní sklonu k páchaniu dopravných priestupkov. Jeho hlavnou výhodou je možnost' vzájomného porovnávania výsledkov, pretože ide o akýsi unifikovaný štandardizovaný nástroj. Na rozdiel od iných dotazníkových metód je možné skúmat’ aj hlbšie vnútorné vzt’ahy medzi faktormi nástroja.

V ideálnom prípade je možné pokúsit’ sa vysvetlit’ kl'účový údaj regresnou analýzou. Takýmto kl'účovým údajom, závislou premennou, môže byt' údaj o počte dopravných nehôd. Nezávislými premennými môžu byt' výsledky nástroja DAQ, prípadne iných nástrojov, ktoré v dopravno-psychologickom výskume kvantifikujú sklony k agresívnemu správaniu, impulzívnosti, schopnosti plánovat’ a podobne.

Zaujímavým námetom na d’alší výskum je práca s vybranými vodičmi, teda tými, ktorých výsledky dosahujú extrémne hodnoty. Na základe dopravno-psychologických nástrojov môže dôjst’ k ich výberu, ale v tomto prípade by museli byt' jednotlivé dotazníky adresné. V d'alšom kroku by bolo na mieste skúmat' vlastnosti týchto vodičov napr. pri jazde v skúšobnom vozidle alebo na jazdnom simulátore. Takýmto spôsobom by bolo možné potvrdit' alebo vyvrátit' hypotézu, že konkrétna psychologická vlastnost' kvalitatívne ovplyvňuje činnost' vodiča.

\section{Pod'akovanie}

Príspevok bol pripravený za podpory grantu: VEGA č. 1/0436/18 - Externality v cestnej doprave, vznik, príčiny a ekonomické dopady dopravných opatrení.

\section{Literatura}

Cohen, J. 1988. Statistical Power Analysis for the Behavioral Sciences. Routledge.

De Winter, J. C. F. a Dodou, D. 2010. The Driver Behaviour Questionnaire as a predictor of accidents: A meta-analysis. Journal of safety research, 41(6), 463-470.

Gheorghiu, A. a Havârneanu, C. 2012. Driving behaviour of a sample of young Romanian drivers. Procediasocial and behavioral sciences, 33, 697-701.

Isaac, A., Shorrock, S. T. a Kirwan, B. 2002. Human error in European air traffic management: the HERA project. Reliability Engineering \& System Safety, 75(2), 257-272.

Jongen, E. M., Brijs, K., Komlos, M., Brijs, T. a Wets, G. 2011. Inhibitory control and reward predict risky driving in young novice drivers-a simulator study. Procedia-Social and Behavioral Sciences, 20, 604-612.

Kalašová, A. a Mikušová, M. 2017. Bezpečnost' cestnej dopravy a dopravná psychológia. EDIS vydavatel'stvo ŽU v Žiline. Žilina. 224.

Martinussen, L. M., Møller, M. a Prato, C. G. 2014. Assessing the relationship between the Driver Behavior Questionnaire and the Driver Skill Inventory: Revealing sub-groups of drivers. Transportation research part F: traffic psychology and behaviour, 26, 82-91. 
Rolison, J. a Moutari, S. 2020. Combinations of factors contribute to young driver crashes. Journal of Safety Research. 73, 171-177.

Wishart, D. E., Davey, J. D. a Freeman, J. E. 2006. An application of the driver attitude questionnaire to examine driving behaviours within an Australian organisational fleet setting. Australasian Road Safety Research, Policing and Education Conference Proceedings, Able Video \& Multimedia Pty Ltd., 1-10.

Stankovianska, Ida. 2018. Základy štatistiky pre inžinierov, Žilina: EDIS, 200. 